DOI: https://doi.org/10.15407/techned2018.04 $: \underline{127}$

\title{
A WAY TO IMPROVE THE ENERGY EFFICIENCY OF PULSE DIELECTTRIC BARRIER DISCHARGE
}

Journal

Publisher

ISSN

Issue

Pages
Tekhnichna elektrodynamika

Institute of Electrodynamics National Academy of Science of Ukraine 1607-7970 (print), 2218-1903 (online)

No 4, 2018 (July/August)

$127-130$

\section{Authors}

\section{I.V. Bozhko*, I.P. Kondratenko**}

Institute of Electrodynamics National Academy of Sciences of Ukraine,

pr. Peremohy, 56, Kyiv, 03057, Ukraine,

e-mail:ws77@ukr.net; dep7ied@ukr.net

* ORCID ID : http://orcid.org/0000-0002-7955-246X

** ORCID ID : http://orcid.org/0000-0003-1914-1383

\section{Abstract}

The researches of unipolar pulse dielectric barrier discharge in a coaxial chamber are executed. It is shown that the capacitive energy that remains on dielectric barrier after graduation forward discharge can effectively ( 99\%) be used in reverse discharge to connect parallel discharge camera a magnetic switch. A magnetic switch is made in such a way that its core saturates immediately following after graduation discharge. The main requirements, when a magnetic switch is designing, are specified. It is shown that the use of harmonized with electrical circuit a magnetic switch allows you to correctly identify density of electrons and their average energy in 
the gas part of the interelectrode gap during discharge. References 7, figures 4, table 1.

Key words: pulse dielectric barrier discharge, energy of a pulsed, dielectric barrier, magnetic switch.

Received: 05.03.2018

Accepted: 28.03.2018

Published:

\section{References}

1. Bozhko I.V., Zozuljov V.I., Kobylchak V.V. SOS-generator for the electric discharge technology used pulse barrier discharge. Tekhnichna Elektrodynamika. 2016. № 2. Pp. 63-68. DOI:

https://doi . org/10.15407/techned2016.02.063 (Ukr)

2. Meerovich L.A., Vatin I.M., Zaitsev E.V., Kandykin V.M. Magnetic generators of pulses. Moskva: Sovetskoe radio, 1968. 476 p. (Rus)

3. Samoylovich V.G., Gibalov V.I., Kozlov K.V. Physical chemistry of barrier discharge. Moskva: Moskovskii gosudarstvennyi universitet, 1989. (Rus)

4. Physical quantities. Handbook by editor Grigorieva I.S., Meilikhova E.Z. Moskva: Energoatomizdat, 1991. 431 p. (Rus)

5. Alexander Fridman. Plasma Chemistry. Philadelphia: Drexel University, 2008. 1022 p.

6. Bozhko. I.V., Serdyuk Y.V. Determination of Energy of a Pulsed Dielectric Barrier Discharge and Method for Increasing Its Efficiency. IEEE Transactions on Plasma Science. 2017. Vol. 45. Issue 12. Pp. 3064-3069.

7. Mericam-Bourdet N., Kirkpatrick M.J., Tuvache F., Frochot D., Odic E. Effect of voltage waveform on dielectric barrier discharge ozone production effciency. European Physics 
Journal: Applied Physics

2012. No 57. 30801(p1-p10).

PDF 